\title{
High thermal and chemical stability in pyrazolate-bridged metal-organic frameworks with exposed metal sites $\dagger$
}

\author{
Valentina Colombo, ${ }^{a b c}$ Simona Galli, ${ }^{c}$ Hye Jin Choi, ${ }^{a b}$ Ggoch Ddeul Han, ${ }^{a b}$ Angelo Maspero, ${ }^{c}$ \\ Giovanni Palmisano, ${ }^{c}$ Norberto Masciocchi ${ }^{c}$ and Jeffrey R. Long ${ }^{* a b}$
}

Received 7th March 2011, Accepted 1st April 2011

DOI: $10.1039 / \mathrm{c} 1 \mathrm{sc00136a}$

Reactions between the tritopic pyrazole-based ligand 1,3,5-tris $\left(1 H\right.$-pyrazol-4-yl)benzene $\left(\mathrm{H}_{3} \mathrm{BTP}\right)$ and transition metal acetate salts in DMF afford microporous pyrazolate-bridged metal-organic frameworks of the type $\mathrm{M}_{3}(\mathrm{BTP})_{2} \cdot x$ solvent ( $\mathrm{M}=\mathrm{Ni}$ (1), Cu, (2), $\mathrm{Zn}$ (3), $\mathrm{Co}$ (4)). Ab-initio X-ray powder diffraction methods were employed in determining the crystal structures of these compounds, revealing $\mathbf{1}$ and $\mathbf{2}$ to exhibit an expanded sodalite-like framework with accessible metal cation sites, while 3 and 4 possess tetragonal frameworks with hydrophobic surfaces and narrower channel diameters. Compounds $\mathbf{1 - 4}$ can be desolvated without loss of crystallinity by heating under dynamic vacuum, giving rise to microporous solids with BET surface areas of 1650, 1860, 930 and $1027 \mathrm{~m}^{2} \mathrm{~g}^{-1}$, respectively. Thermogravimetric analyses and powder X-ray diffraction measurements demonstrate the exceptional thermal and chemical stability of these frameworks. In particular, 3 is stable to heating in air up to at least $510^{\circ} \mathrm{C}$, while 1 is stable to heating in air to $430{ }^{\circ} \mathrm{C}$, as well as to treatment with boiling aqueous solutions of $\mathrm{pH} 2$ to 14 for two weeks. Unexpectedly, $\mathbf{2}$ and $\mathbf{3}$ are converted into new crystalline metal-organic frameworks upon heating in boiling water. With the combination of stability under extreme conditions, high surface area, and exposed metal sites, it is anticipated that 1 may open the way to testing metal-organic frameworks for catalytic processes that currently employ zeolites.

\section{Introduction}

A large segment of the global economy is based on the use of natural and synthetic zeolites in chemical industries as detergents, adsorbents/desiccants and heterogeneous catalysts. ${ }^{1}$ Consequently, worldwide consumption of these materials is estimated at about 4-4.5 million metric tons per year. ${ }^{1 c, d}$ As purely inorganic materials, zeolites are extraordinarily robust and provide moderately high surface areas, which together facilitate catalytic activity. Nevertheless, their performance can be limited by the stiffness of the framework, whose features, above all pore size and surface functionalization, are not readily modified using self-assembly approaches. Over the past decade, metal-organic frameworks have begun to emerge as possible alternatives for such applications. These materials are hybrid compounds built up from metal ions or metal-based clusters

${ }^{a}$ Department of Chemistry, University of California, Berkeley, California, 94720, U. S. A. E-mail: jrlong@berkeley.edu

${ }^{b}$ Materials Sciences Division, Lawrence Berkeley National Laboratory, Berkeley, California, 94720, U. S. A.

'Dipartimento di Scienze Chimiche e Ambientali, Università dell'Insubria, via Valleggio 11, I-22100 Como, Italy

$\uparrow$ Electronic supplementary information (ESI) available: Crystallographic files (CIF), detailed experimental procedures, crystal data and plots showing additional data (PDF). See DOI: $10.1039 / \mathrm{c} 1 \mathrm{sc} 00136 \mathrm{a}$ linked via various organic bridging ligands to form a threedimensional skeleton, frequently with an extraordinarily high surface area. ${ }^{2}$ Compared to zeolites, metal-organic frameworks typically display a considerable degree of tunability, achievable by judicious selections of inorganic and organic components, or via post-synthetic modification of the surface. ${ }^{3}$ Depending upon the metal ions and organic linkers incorporated in the framework, key chemical and physical properties, such as pore size, surface area, guest binding capability, catalytic activity, can potentially be finely modulated. This has enabled researchers to generate metal-organic frameworks of interest for a variety of applications, including gas storage,${ }^{4}$ molecular separations,${ }^{5}$ and heterogeneous catalysis. ${ }^{6}$

Although metal-organic frameworks have in rare instances displayed thermal stability up to $500{ }^{\circ} \mathrm{C},{ }^{7}$ none yet approach the robustness of zeolites, a disadvantage further worsened by problems generally related to their low chemical stability. This is particularly true for those systems based on divalent metal cations combined with organocarboxylate bridging ligands, ${ }^{8}$ which can be subject to hydrolysis and thermal decomposition in the presence of moisture. ${ }^{9}$ In this regard, it is clearly beneficial to discover new high-surface area metal-organic frameworks that are stable toward diverse environments such as air, water, acidic and basic media, and even extreme temperatures and pressures. Such advancements will extend the utility of metal-organic 
frameworks towards a variety of applications where zeolites have been playing a major role.

Along this line, our strategy has involved the use of polyazolate-bridging ligands, ${ }^{10}$ that can lead to frameworks with strong metal-nitrogen bonds, providing a greater chemical and thermal stability compared to their carboxylate-based counterparts. Employing polyazolate heterocycles, the strength of the resulting $\mathrm{M}-\mathrm{N}$ bonds can be predicted to be closely related to the $\mathrm{p} K_{\mathrm{a}}$ values for the deprotonation of the $\mathrm{N}-\mathrm{H}$ bond. Indeed, increased stability has been observed for frameworks generated from organic ligands functionalized with 1,2,3-triazole $\left(\mathrm{p} K_{\mathrm{a}}=\right.$ 13.9) ${ }^{11}$ than for analogues based upon tetrazole $\left(\mathrm{p} K_{\mathrm{a}}=4.9\right) .{ }^{11,12}$ Imidazole, with an even higher $\mathrm{p} K_{\mathrm{a}}$ of $18.6,{ }^{11}$ has been shown to afford frameworks of still greater thermal stability ( $T_{\mathrm{dec}}$ up to $390{ }^{\circ} \mathrm{C}$ ) and some chemical resistance to alkalinity and boiling solvents such as water, methanol and benzene. ${ }^{7 a}$ In particular, however, organic ligands functionalized with pyrazole $\left(\mathrm{p} K_{\mathrm{a}}=\right.$ 19.8), ${ }^{11}$ are of interest for the synthesis of robust pyrazolatebridged frameworks.

A number of pyrazolate-based metal-organic frameworks exhibiting exceptional stability have already been realized. For example, 1,4-bis(1H-pyrazol-4-yl)benzene $\left(1,4-\mathrm{H}_{2} \mathrm{BDP}\right)$ was found to react with salts of cobalt(II), ${ }^{13}$ nickel(II) or zinc(II) ${ }^{7 d, e}$ to afford frameworks exhibiting good thermal stability $\left(T_{\mathrm{dec}}=420\right.$ $460{ }^{\circ} \mathrm{C}$ ) and permanent porosity with Langmuir surface areas between 1600 and $2670 \mathrm{~m}^{2} \mathrm{~g}^{-1}$. Employing instead the bent molecule 1,3-bis(1H-pyrazol-4-yl)benzene (1,3- $\left.\mathrm{H}_{2} \mathrm{BDP}\right)$ results in a double-walled zinc-based framework of even greater thermal stability $\left(T_{\mathrm{dec}}=500{ }^{\circ} \mathrm{C}\right)$, which further shows chemical stability in a hot acidic solution $(\mathrm{pH} 3){ }^{7 e}$ The thermal stability of pyrazolate-based materials was again observed for the cubic frameworks $\mathrm{Ni}_{8} \mathrm{~L}_{6}(\mathrm{OH})_{4}\left(\mathrm{H}_{2} \mathrm{O}\right)_{2}$ with $\mathrm{L}=4,4^{\prime}$-bis $(1 H$-pyrazol-4yl)biphenyl $\left(T_{\mathrm{dec}}=420{ }^{\circ} \mathrm{C}\right)$ or 2,6-bis( $1 H$-pyrazol-4-yl)pyrrolo [3,4-f]isoindole-1,3,5,7(2H,6H)-tetrone $\left(T_{\mathrm{dec}}=410{ }^{\circ} \mathrm{C}\right) .^{7 f}$ Furthermore, a $\mathrm{Cu}(\mathrm{I})$ framework based on 3,3',5,5'-tetramethyl$4,4^{\prime}$-bipyrazolate $\left(\mathrm{H}_{2} \mathrm{Me}_{4} \mathrm{bpz}\right)$ was found stable up to $500{ }^{\circ} \mathrm{C}$ in nitrogen atmosphere but also in air atmosphere with a decomposition temperature of above $400{ }^{\circ} \mathrm{C} .{ }^{7 h}$ On the whole, the thermal and chemical stability of pyrazolate-based frameworks is indeed significantly increased relative to the tetrazolate- and triazolate-bridged frameworks. We note, however, that none of these high-stability pyrazolate-based frameworks possess internal surfaces bearing open metal coordination sites.

Exposed metal cations within metal-organic frameworks have been demonstrated to lead to outstanding properties for hydrogen storage, ${ }^{14}$ gas separations, ${ }^{4 b-e, 12,15}$ and catalysis. ${ }^{6}$ Among the azolate-based metal-organic frameworks of this type, $\mathrm{Mn}_{3}\left[\left(\mathrm{Mn}_{4} \mathrm{Cl}\right)_{3}(\mathrm{BTT})_{8}\right]_{2} \cdot 20 \mathrm{MeOH}\left(\mathrm{Mn}-\mathrm{BTT}, \mathrm{H}_{3} \mathrm{BTT}=\right.$ 1,3,5-tris(2H-tetrazol-5-yl)benzene), a rigid high-surface area framework with an expanded sodalite-like structure and exposed $\mathrm{Mn}^{2+}$ sites, exhibited a high $\mathrm{H}_{2}$ binding affinity ${ }^{14 a}$ and Lewis acid catalysis. ${ }^{6 c}$ Unfortunately, the relatively low thermal stability $\left(T_{\mathrm{dec}} \approx 200^{\circ} \mathrm{C}\right)$ and water-sensitivity of this tetrazolate-bridged framework limits its utility. Attempts to synthesize analogous triazolate-based structures afforded the more stable framework $\mathrm{H}_{3}\left[\left(\mathrm{Cu}_{4} \mathrm{Cl}\right)_{3}(\mathrm{BTTri})_{8}\right]$ (Cu-BTTri, $\mathrm{H}_{3}$ BTTri $=1,3,5$-tris $(1 \mathrm{H}$ 1,2,3-triazol-5-yl)benzene). ${ }^{12}$ With improved thermal stability $\left(T_{\mathrm{dec}}=270^{\circ} \mathrm{C}\right)$, this compound exhibits substantial chemical resistance, retaining its porous structure in dilute $\mathrm{HCl}$ solution
$(\mathrm{pH} 3)$ at room temperature or in boiling water for 3 days. Moreover, its stability in basic media enabled grafting of ethylenediamine on the open $\mathrm{Cu}^{2+}$ sites, leading to a record heat of $\mathrm{CO}_{2}$ adsorption for a metal-organic framework.

In order to achieve a still greater level of stability, approaching that of zeolites, pyrazolate-bridged analogues of this important structure type were sought. Herein, we report the synthesis of the new linker 1,3,5-tris(1H-pyrazol-4-yl)benzene $\left(\mathrm{H}_{3} \mathrm{BTP}\right.$, see Fig. 1a), and its use in generating a series of exceptionally robust metal-organic frameworks, two of which adopt the Mn-BTT structure and feature exposed metal cation sites.

\section{Results and discussion}

\section{Synthesis and structure of sodalite-type $\mathrm{Ni}_{3}(\mathrm{BTP})_{2}$ and $\mathrm{Cu}_{3}(\mathrm{BTP})_{2}$ phases}

Reaction of $\mathrm{H}_{3} \mathrm{BTP}$ with nickel(II) or copper(II) acetate in DMF at $160{ }^{\circ} \mathrm{C}$ afforded, upon washing with methanol and drying in air, $\mathrm{Ni}_{3}(\mathrm{BTP})_{2} \cdot 3 \mathrm{DMF} \cdot 5 \mathrm{CH}_{3} \mathrm{OH} \cdot 17 \mathrm{H}_{2} \mathrm{O}(\mathbf{1})$ and $\mathrm{Cu}_{3}(\mathrm{BTP})_{2} \cdot 8-$ $\mathrm{CH}_{3} \mathrm{OH} \cdot 10 \mathrm{H}_{2} \mathrm{O}$ (2) as yellow and brown microcrystalline powders, respectively. Preliminary powder X-ray diffraction acquisitions showed both compounds to be isomorphous with the sodalite-like structure of Mn-BTT. ${ }^{14 a}$ The latter compound consists of chloride-centered $\left[\mathrm{Mn}_{4}\left(\mu_{4}-\mathrm{Cl}\right)\right]^{7+}$ squares linked via triangular $\mathrm{BTT}^{3-}$ ligands to form a porous, three-dimensional framework in which each metal center further has a bound DMF molecule directed into the pores. Overall, the framework has an anionic charge, which is balanced by $\left[\mathrm{Mn}(\mathrm{DMF})_{6}\right]^{2+}$ cations included in the pores. Despite the great similarity in size and shape between $\mathrm{H}_{3} \mathrm{BTT}$ and $\mathrm{H}_{3} \mathrm{BTP}$, our attempts at synthesizing a Mn-BTT analogue using $\mathrm{H}_{3}$ BTP and various metal chlorides were unsuccessful. Instead, the use of metal acetates in DMF was found to promote the deprotonation of the pyrazole ligand to form $\mathrm{M}-\mathrm{N}$ bonds and the extended sodalite-like framework structure of $\mathbf{1}$ and $\mathbf{2}$. As assessed by X-ray powder structure analysis, $\mathbf{1}$ and $\mathbf{2}$ are isomorphous, but not isostructural with Mn-BTT. Specifically, the $\mu_{4}$ bridging chloride anion present in Mn-BTT, is absent in $\mathbf{1}$ and $\mathbf{2}$, as evidenced by elemental analysis and X-ray fluorescence (see Fig. S6, ESI $\dagger$ ) and consideration on their structural features (see below).

Compounds 1 and $\mathbf{2}$ crystallize (see Fig. 1) in the cubic space group $\operatorname{Pm} \overline{3} m$, with the metal ions lying on crystallographic twofold axes and arranged in tetranuclear cores of rigorous, crystallographically-imposed square symmetry, with $\mathrm{M} \cdots \mathrm{M}$ edges of 3.118(6) and 3.013(7) $\AA$, for $\mathbf{1}$ and 2, respectively. The chlorocentered $\mathrm{Mn}_{4}$ squares in Mn-BTT showed $\mathrm{Mn} \cdots \mathrm{Mn}$ distances of 3.70(3) $\mathrm{A}$, in agreement with the presence of the inner $\mu_{4}-\mathrm{Cl}$ ion and leading to a larger accessible empty volume (as measured, $e$. $g$, by the BET specific area, vide infra) ${ }^{23}$ In 1 and 2 , each $\mathrm{M} \cdots \mathrm{M}$ edge is bridged by pyrazolate groups from two distinct $\mathrm{BTP}^{3-}$ ligands, resulting in a square-planar coordination geometry at each metal ion. Residing on a $3 m$ crystallographic site, each $\mathrm{BTP}^{3-}$ ligand employs its three pyrazolate substituents to bridge $\mathrm{M} \cdots \mathrm{M}$ edges of three different $\mathrm{M}_{4}$ squares. Each square is connected to eight adjacent squares, generating a rigid threedimensional framework. Thus, the framework structure features octahedral cavities centered at $[1 / 2,1 / 2,1 / 2]$, with BTP $^{3-}$ ligands spanning each face and $\mathrm{M}_{4}$ squares truncating each vertex to give 

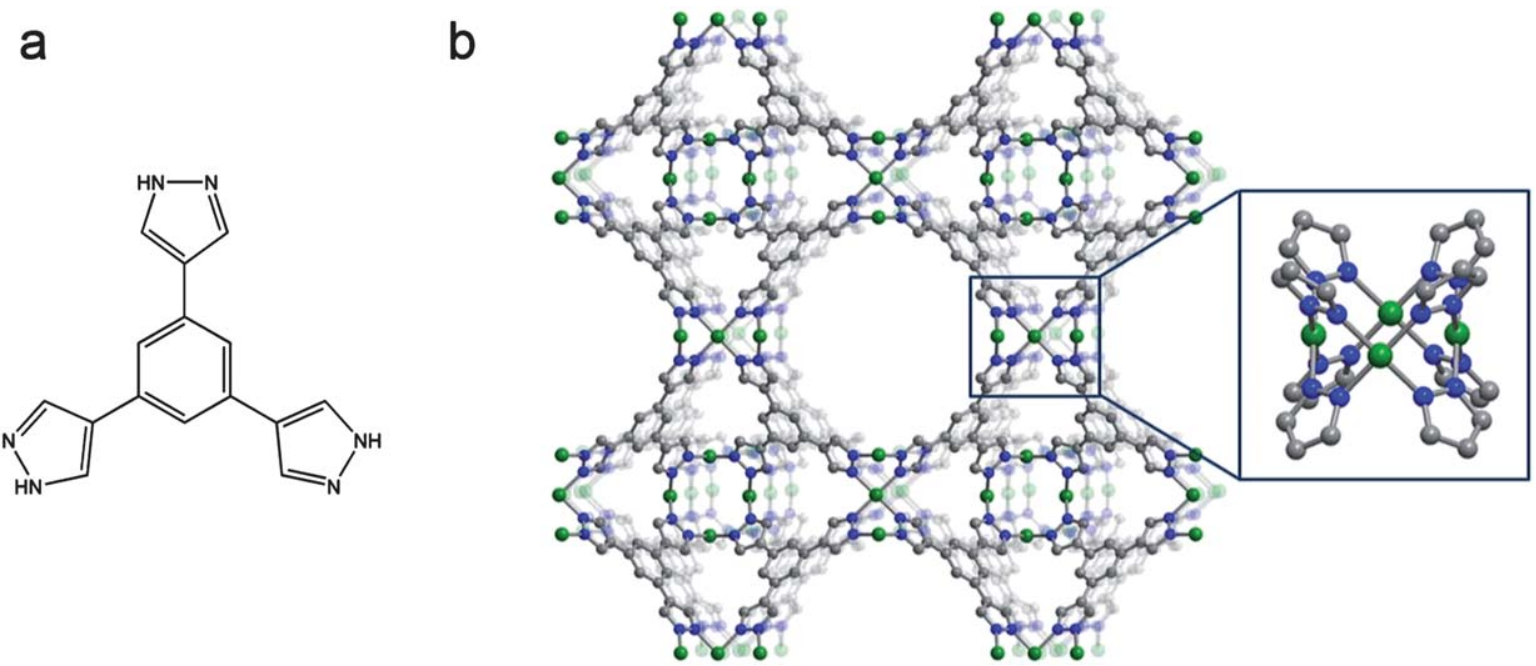

Fig. 1 Scheme of the pyrazole-based ligand 1,3,5-tris $\left(1 H\right.$-pyrazol-4-yl)benzene, $\mathrm{H}_{3} \mathrm{BTP}$ (a) and portions of the structure of $\mathrm{Ni}_{3}(\mathrm{BTP})_{2} \cdot 3$ $\mathrm{CH}_{3} \mathrm{OH} \cdot 10 \mathrm{H}_{2} \mathrm{O}(\mathbf{1 m})$, as determined from powder X-ray diffraction data. (b) Green, blue, and gray spheres represent $\mathrm{Ni}, \mathrm{N}$ and $\mathrm{C}$ atoms, respectively; $\mathrm{H}$ atoms and solvent molecules are omitted for clarity. The inset shows the square-planar $\mathrm{Ni}_{4}$ cluster bridged by eight pyrazolate rings. The compound $\mathrm{Cu}_{3}(\mathrm{BTP})_{2} \cdot 8 \mathrm{CH}_{3} \mathrm{OH} \cdot 10 \mathrm{H}_{2} \mathrm{O}(2)$ is isostructural. Selected bond distances $(\AA)$ and angles $\left({ }^{\circ}\right)$ for the structures of $\mathbf{1}$ and 2, respectively: $\mathrm{M}-\mathrm{N} 2.0200(4)$ and 2.1225(6); M - M 3.118(6) and 3.013(7); N-M-N 77.4(2), 102.6(2), 178.9(3) and 73.7(2), 106.0(2), 174.4(3); M-N-N 64.2(1), 116.7(1) and 67.1(1), 117.3(1). Please note that in both cases, the crystallographically independent portion of the $\mathrm{BTP}^{3-}$ ligand has been modeled by means of a rigid body ${ }^{19}$

an expanded sodalite cage unit. The sharing of squares between neighboring cage units along the three unit cell axes, results in one-dimensional channels running parallel to the cell axes. These channels have a wide diameter of nearly $10 \AA$ (based upon van der Waals radii). Yet, only a very small entrance, possibly limiting the size and shape of adsorbable gases, allows access to the $c a$. 6 - $\AA$ cavity within the octahedral, sodalite-like cage units. Based upon van der Waals radii, a total void volume of 66 and $69 \%$ is estimated from the structures of $\mathbf{1}$ and 2 , respectively. ${ }^{16,17}$ The slight increase of unit cell and void volumes from $\mathbf{1}$ to $\mathbf{2}$ is consistent with the ionic radii of square-planar $\mathrm{Ni}^{2+}$ and $\mathrm{Cu}^{2+}$ ions (0.63 and $0.71 \AA$, respectively), which result in longer $\mathrm{Cu}-\mathrm{N}$ bonds and a slightly expanded framework for 2 . The electron density residues present in the Fourier difference maps, as resulting from the modelling of the frameworks alone, clearly indicate that: (i) both cavities and channels contain guest solvent molecules, and (ii) solvents such as DMF, $\mathrm{CH}_{3} \mathrm{OH}$, and water can bind to open metal coordination sites. As evidenced by the isolation and characterization of different solvated forms, coordinated solvent is indeed likely to be present at an apical position, protruding into the large channels and creating a square-pyramidal coordination at each metal center. ${ }^{18}$

In examining the chemical stability of $\mathbf{2}$, some amount of the solid was refluxed in a concentrated basic $(\mathrm{NaOH}, \mathrm{pH} 14)$ solution. A brown deposit isolated from the solution turned out to be a distinct new phase, $\mathrm{Cu}_{3}(\mathrm{BTP})_{2} \cdot 6 \mathrm{H}_{2} \mathrm{O}\left(\mathbf{2}^{\prime}\right)$, which could be also obtained by refluxing $\mathbf{2}$ in an acid solution $(\mathrm{HCl}, \mathrm{pH} 3)$. This microcrystalline product appears, however, to be non-porous, as evidenced by a thermogravimetric analysis showing no weight loss up to decomposition (see Fig. S7, ESI $\dagger$ ). Its powder diffraction trace could be easily indexed to a $R$-centered trigonal unit cell, with the likely presence of $c$-type glide planes. Possible space group candidates are therefore $R \overline{3} c$ and $R 3 c$, which share the same systematic extinction conditions. Indeed, a structureless
Le Bail fit matched well with the observed diffraction pattern (see Table S1, ESI $\dagger$ ). Unfortunately, compound $\mathbf{2}^{\prime}$ has thus far resisted all attempts of structural resolution, although clear indications of a nearly layered disposition of the $\mathrm{BTP}^{3-}$ ligands (parallel to $a b$ ) and of trinuclear $\mathrm{Cu}_{3}$ units were found. Work is in progress to assess the complete crystal structure, but the results, if any, will be postponed to a future contribution.

\section{Synthesis and structure of tetragonal $\mathrm{Zn}_{3}(\mathrm{BTP})_{2}$ and $\mathrm{Co}_{3}(\mathrm{BTP})_{2}$ phases}

Since the discovery of Mn-BTT, it has been established that isostructural tetrazolate-based frameworks can be synthesized with a variety of other transition-metal ions, including $\mathrm{Cr}^{2+}, \mathrm{Fe}^{2+}$, $\mathrm{Co}^{2+}, \mathrm{Ni}^{2+}, \mathrm{Cu}^{2+}$ and $\mathrm{Cd}^{2+} \cdot{ }^{14,20}$ Similarly, we sought to obtain pyrazolate-bridged analogues of $\mathrm{Ni}_{3}(\mathrm{BTP})_{2}$ and $\mathrm{Cu}_{3}(\mathrm{BTP})_{2}$ incorporating other transition-metal ions with a high affinity for nitrogen-based ligands. ${ }^{21}$ After numerous attempts applying different reaction conditions, a white microcrystalline powder was obtained through addition of triethylamine to a solution of $\mathrm{Zn}\left(\mathrm{CF}_{3} \mathrm{SO}_{3}\right)_{2}$ and $\mathrm{H}_{3} \mathrm{BTP}$ in DMF. Due to the high $\mathrm{p} K_{\mathrm{a}}$ of the pyrazole rings, either base or high temperature is essential to force the reaction to proceed. ${ }^{22}$ Washing with wet methanol followed by drying in vacuo resulted in a compound of formulation $\mathrm{Zn}_{3}(\mathrm{BTP})_{2} \cdot 4 \mathrm{CH}_{3} \mathrm{OH} \cdot 2 \mathrm{H}_{2} \mathrm{O}$ (3). As might be expected for transition-metal ions favoring tetrahedral stereochemistry, such as zinc(II) and cobalt(II), $\mathrm{Co}_{3}(\mathrm{BTP})_{2} \cdot 8 \mathrm{CH}_{3} \mathrm{OH} \cdot 10 \mathrm{H}_{2} \mathrm{O}$ (4) was synthesized following the same reaction procedure.

Compounds $\mathbf{3}$ and $\mathbf{4}$ crystallize in the tetragonal space group $P 4_{2} / \mathrm{ncm}$. The local coordination geometry can be appreciated from the depiction at the bottom of Fig. 2, while the overall framework structure is shown at the top. The structures contain tetrahedrally coordinated metal(II) centers arranged in collinear chains running along [110] (and equivalent directions), with 

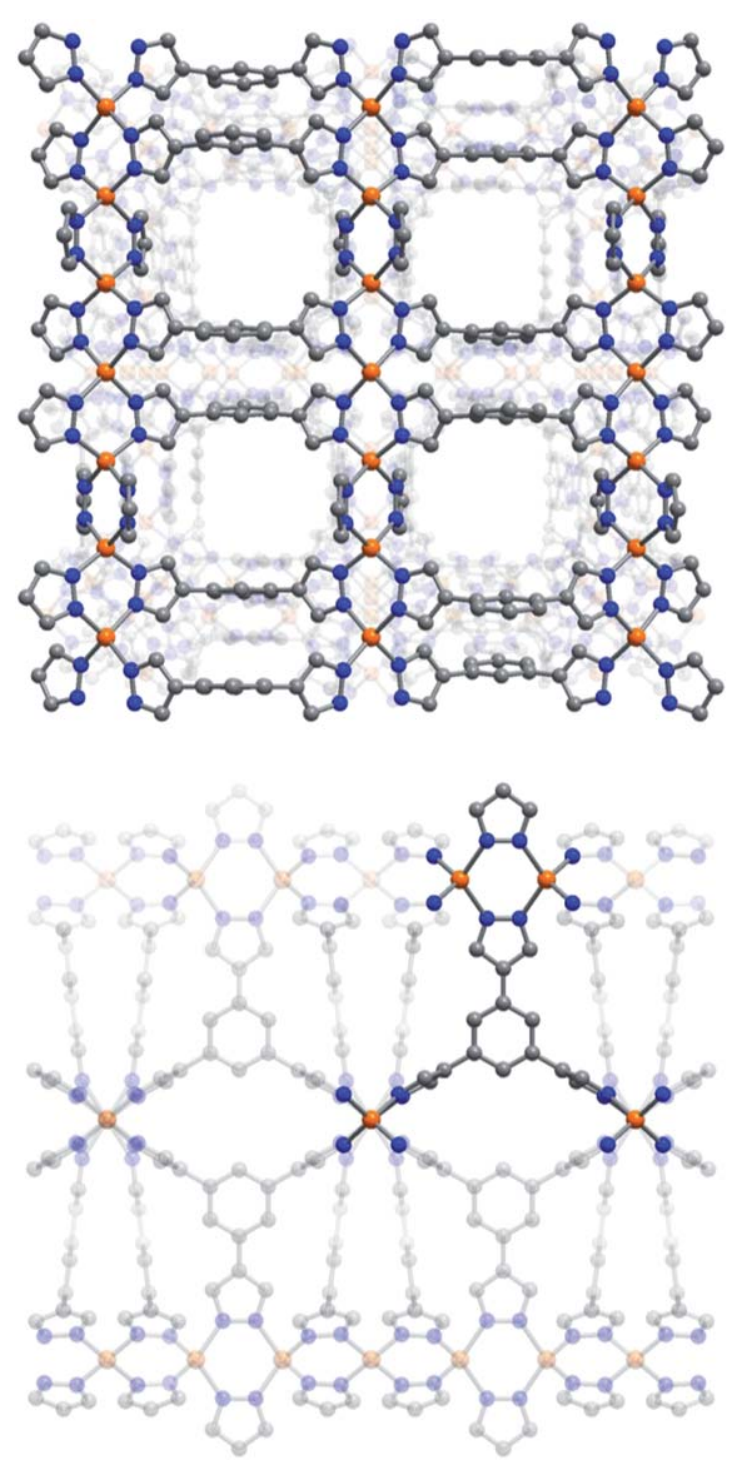

Fig. 2 Portions of the structure of $\mathrm{Zn}_{3}(\mathrm{BTP})_{2} \cdot 4 \mathrm{CH}_{3} \mathrm{OH} \cdot 2 \mathrm{H}_{2} \mathrm{O}$ (3), determined by powder X-ray diffraction analysis, as viewed along the $c$ (upper) axis and [110] direction (bottom). Orange, blue and gray spheres represent $\mathrm{Zn}, \mathrm{N}$ and $\mathrm{C}$ atoms, respectively; $\mathrm{H}$ atoms and solvent molecules are omitted for clarity. The compound $\mathrm{Co}_{3}(\mathrm{BTP})_{2} \cdot 8$ $\mathrm{CH}_{3} \mathrm{OH} \cdot 10 \mathrm{H}_{2} \mathrm{O}(4)$ is isostructural. Selected bond distances $(\AA)$ and angles $\left({ }^{\circ}\right)$ for the structures of $\mathbf{3}$ and $\mathbf{4}$, respectively: M-N 2.077(6), 2.053 (6), 2.106(7) and 2.124(7), 2.035(8), 2.046(9); M $\cdots \mathrm{M} 3.654(1)$ and 3.748 (1); N-M-N 102.3(4)-127.3(4) and 97.7(4)-120.8(2); M-N-N 120.0(4), 121.3(2) 123.1(2) and 119.1(3), 119.7(3), 125.8(3). Please note that in both cases, the crystallographically independent portion of the $\mathrm{BTP}^{3-}$ ligand has been modeled by means of a rigid body. ${ }^{19}$

pyrazolate-bridged intermetallic separations of 3.748(1) and 3.654(1) $\AA$ for Co and $\mathrm{Zn}$, respectively. The $\mathrm{BTP}^{3-}$ ligands are bisected by a crystallographic two-fold axis and possess one pyrazolate moiety in plane with the inner arene and the other two making a dihedral angle of about $64^{\circ}$ to the benzene core. Each chain connects to three adjacent chains to afford a threedimensional framework. Porosity is apparent in the structures, with one-dimensional channels of slightly less than $4 \AA$-diameter, running parallel to $c$ and filled with guest solvent molecules. The surfaces exposed within these channels appear to be only $\pi$-rings, thus imparting a hydrophobic character. Overall, the accessible void volume reaches 46 and $50 \%$ for the structures of $\mathbf{3}$ and $\mathbf{4}$, respectively. ${ }^{16}$ Unlike $\mathbf{1}$ and $\mathbf{2}$, these compounds do not feature metal-bound solvent molecules that could potentially be removed to generate coordinatively-unsaturated metal centers.

When compound 3 was heated in boiling water, a new crystalline phase $\mathrm{Zn}_{12}\left[\mathrm{Zn}_{2}\left(\mathrm{H}_{2} \mathrm{O}\right)_{2}\right]_{6}(\mathrm{BTP})_{16}\left(\mathbf{3}^{\prime}\right)$ was obtained, as identified by X-ray powder diffraction. The same phase was also isolated through the reaction of $\mathbf{3}$ in a concentrated basic solution $(\mathrm{NaOH}, \mathrm{pH} 14)$ for $30 \mathrm{~min}$. Although 3 is highly resistant to high temperatures (up to $510{ }^{\circ} \mathrm{C}$ ), the solid-state transformation in basic $\mathrm{pH}$ conditions occurs at room temperature in a very short time, indicating that the presence of water is critical to its instability. Compound $\mathbf{3}^{\prime}$ crystallizes in the cubic space group $P n \overline{3} n$. The best structural model derived from our X-ray powder diffraction analysis was found to contain one-dimensional chains running along the three crystallographic axes. Two crystallographically distinct zinc(II) centers, referred to as $\mathrm{Zn} 1$ and $\mathrm{Zn} 2$, alternate along the chains (see Fig. 3). Site Zn1 possesses a tetrahedral stereochemistry, with coordination by four nitrogen atoms belonging to the pyrazolate moieties of four distinct $\mathrm{BTP}^{3-}$ ligands. Situated at the vertices of a $\left[\mathrm{Zn}_{2}\left(\mathrm{H}_{2} \mathrm{O}\right)_{2}\right]^{4+}$ rhombic unit, $\mathrm{Zn} 2$ shows a cis- $\mathrm{ZnN}_{2} \mathrm{O}_{2}$ tetrahedral stereochemistry, where the nitrogen atoms belong to pyrazolate groups from two distinct $\mathrm{BTP}^{3-}$ ligands. Due to the orientational disorder affecting the rhombic units (which reside on a crystallographic four-fold axis), along each chain, Zn1 may be bridged, by the $\mathrm{BTP}^{3-}$ ligands, either to $\mathrm{Zn} 2$, via a $\mathrm{Zn}-\mathrm{N}$ bond, or to a water molecule, via a $\mathrm{N} \cdots \mathrm{HO}$ hydrogen bond (see Fig. S5, ESI $\dagger$ ). Given the overall coordination mode of the $\mathrm{BTP}^{3-}$ ligands, which employ all of their nitrogen atoms to form bonds, the chains are mutually connected to give a dense, three-dimensional framework with no voids or channels for hosting solvent. As expected in the absence of guest solvent molecules, thermogravimetric analysis shows no weight loss for the compound up to decomposition, which occurs at a rather high temperature of above $400^{\circ} \mathrm{C}$ (see Fig. S8, ESI $\dagger$ ).

\section{Gas adsorption properties}

Prompted by their porous structures, we evaluated the permanent porosity of compounds $\mathbf{1 - 4}$ by collecting $\mathrm{N}_{2}$ adsorption isotherms at $77 \mathrm{~K}$. Complete removal of coordinating solvents without collapsing the structure is not always trivial, however, due to an activation barrier which should be overcome by applying vacuum and high temperatures, often subsequent to solvent exchange using a volatile coordinating solvent such as methanol. To determine the optimal activation temperatures of the methanol-exchanged phases, the samples were heated under dynamic vacuum at gradually increasing temperatures, while $\mathrm{N}_{2}$ adsorption was repeatedly measured at each stage. From the $\mathrm{N}_{2}$ isotherm measurements, the best activation method for compounds $\mathbf{1}$ and $\mathbf{2}$ was determined to be application of dynamic vacuum at $250{ }^{\circ} \mathrm{C}$ for at least two days. With no bound solvent, 3 and 4 can be activated by heating under vacuum at the lower temperature of $160{ }^{\circ} \mathrm{C}$ for two days.

The optimally desolvated materials were found to adsorb significant amounts of $\mathrm{N}_{2}$ at $77 \mathrm{~K}$, displaying Type I adsorption isotherms characteristic of microporous solids (see Fig. 4). 

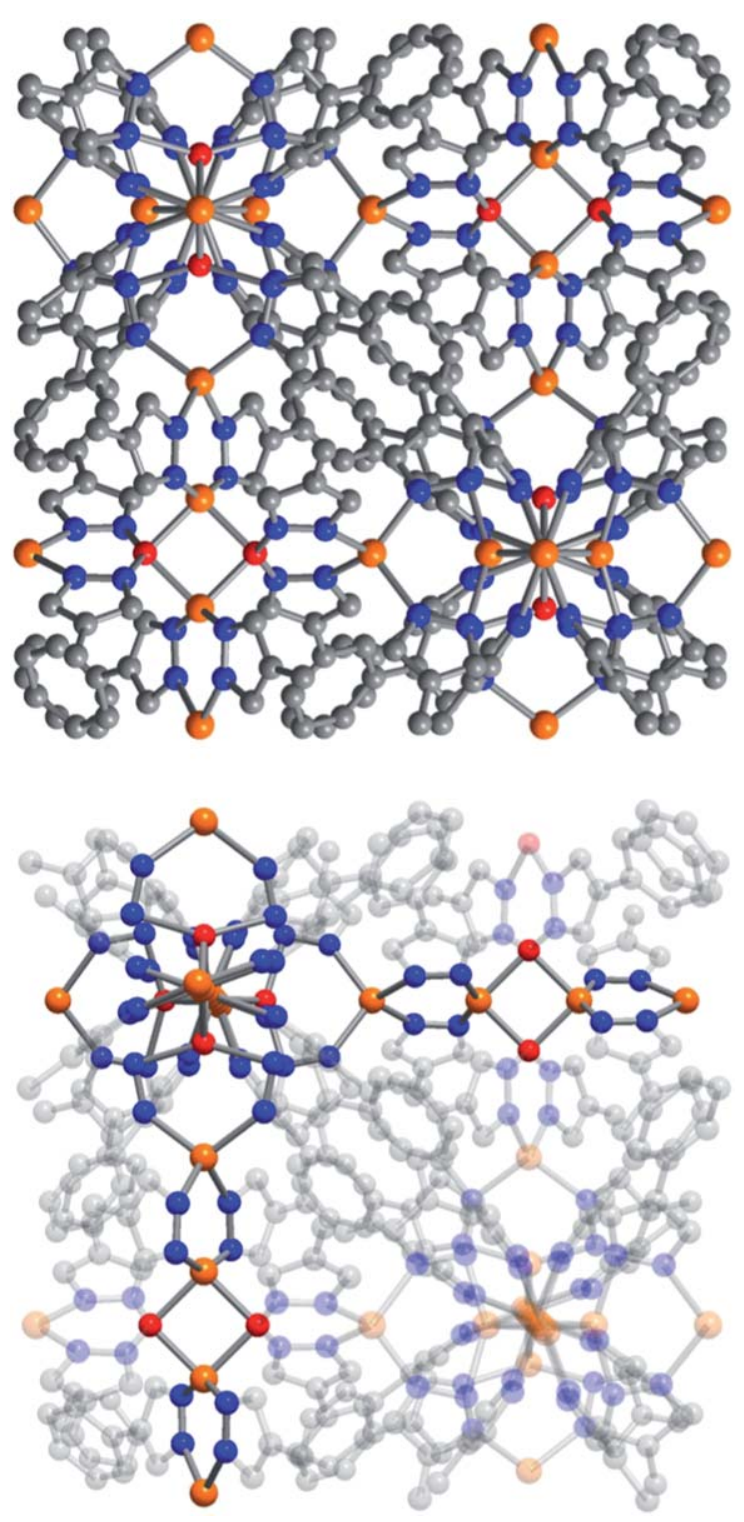

Fig. 3 Portions of the molecular structure of $\mathrm{Zn}_{12}\left[\mathrm{Zn}_{2}\left(\mathrm{H}_{2} \mathrm{O}\right)_{2}\right]_{6}(\mathrm{BTP})_{16}$ $\left(\mathbf{3}^{\prime}\right)$ analyzed by powder $\mathrm{X}$-ray diffraction as viewed along $a$ axis. Orange, red, blue and gray spheres represent $\mathrm{Zn}, \mathrm{O}, \mathrm{N}$ and $\mathrm{C}$ atoms, respectively; $\mathrm{H}$ atoms are omitted for clarity. For a description of the local disorder affecting the $\mathrm{Zn}_{2} \mathrm{O}_{2}$ fragment see ESI $\dagger$. Selected bond distances $(\AA)$ and angles $\left(^{\circ}\right)$ for the structure of $\mathbf{3}^{\prime}: \mathrm{Zn}-\mathrm{N}$ 2.07(2), 2.099(6); $\mathrm{Zn}-\mathrm{O}$ 1.97(2); $\mathrm{Zn} \cdots \mathrm{Zn}$ 2.97(1), 3.13(5); N-Zn-N 106.7(2), 115.2(4), 140.8(2); N-Zn-O 85.3(2); O-Zn-O 82(2); Zn-N-N 101(1), 129.0(3); Zn-O-N 84(1), 129(2). Please note that in both cases, the crystallographically independent portion of the $\mathrm{BTP}^{3-}$ ligand has been modeled by means of a rigid body. ${ }^{19}$

Fitting the $\mathrm{N}_{2}$ isotherms afforded BET surface areas of 1650(20), $1860(10), 930(10)$ and $1027(3) \mathrm{m}^{2} \mathrm{~g}^{-1}$ and Langmuir surface areas of 1900(13), 2159(10), 1242(11) and 1588(40) $\mathrm{m}^{2} \mathrm{~g}^{-1}$ for 1, 2, 3 and 4 , respectively. Perhaps owing to a smaller unit cell dimension, the surface areas of $\mathbf{1}$ and $\mathbf{2}$ are slightly lower than observed for Mn-BTT, which, thanks to the $\left(\mu_{4}-\mathrm{Cl}\right.$ induced) inflation of the inner $\mathrm{Mn}_{4}$ core (vide supra), displayed a BET surface area of $2100 \mathrm{~m}^{2} \mathrm{~g}^{-1}$. ${ }^{14 a}$ Actually, for 3D isostructural materials sharing the same ligand and slightly different cores, also the empty volume is significantly affected by the cooperative change in size

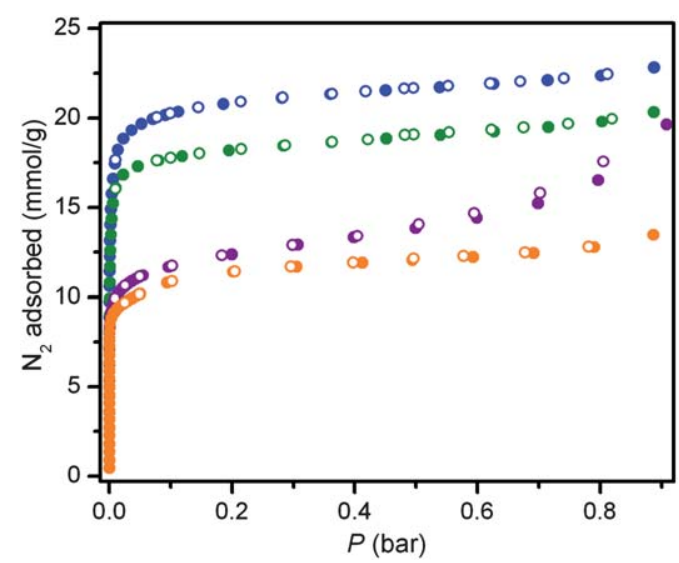

Fig. 4 Nitrogen adsorption isotherms measured at $77 \mathrm{~K}$ for $\mathbf{1}$ (green), 2 (blue) 3 (orange) and $\mathbf{4}$ (purple). Filled and empty symbols represent adsorption and desorption, respectively.

of the metallic nodes, here addressed by the $\mathrm{M} \cdots \mathrm{M}$ contacts in the inner $\mathrm{M}_{4}$ square (with a linear inflation, on passing from $\mathrm{Ni}_{4}$ (or $\left.\mathrm{Cu}_{4}\right)$ to $\left[\left(\mu_{4}-\mathrm{Cl}\right) \mathrm{Mn}_{4}\right]$, larger than $20 \%$, see above). Similarly, a ca. $0.1 \AA$ increase of the metal radius on passing from $\mathrm{Cu}$ to $\mathrm{Pd}$ in the sodalitic $\mathrm{M}(n \text {-pymo })_{2}$ frameworks $\left(n\right.$-pymo ${ }^{-}=$pyrimidin$n$-olate) allowed the increase of nearly $30 \%$ of the void volume and of $c a .80 \%$ of the BET surface area. ${ }^{23}$ Notably, the increase in surface area from $\mathbf{1}$ to $\mathbf{2}$ is also consistent with their unit cell dimension and void volume, which is ultimately related to the ionic radii of the two metal ions (see above). The surface area of $\mathbf{3}$ and 4 are also consistent with that of $\mathrm{Zn}(1,3-\mathrm{BDP})$ and $\mathrm{Co}(1,3-$ BDP), which display much similarity in the framework connectivity and pore size. ${ }^{7 e}$

\section{Thermal behavior}

In order to probe the thermal stability of the new compounds, thermogravimetric analyses were performed, combined with in situ variable-temperature powder $\mathrm{X}$-ray diffraction experiments. While the thermogravimetric analyses were carried out under $\mathrm{N}_{2}$ for as-synthesized compounds $\mathbf{1 - 4}$, complete and detailed characterization of the thermal behaviors of 1-3 were carried out in air by means of variable-temperature diffraction experiments.

As depicted in Fig. 5 the thermogravimetric trace of 1 shows a weight loss of $30 \%$ between 30 and $150{ }^{\circ} \mathrm{C}$, corresponding to the partial evolution of guest solvent (4 methanol and 16 water molecules corresponds to $30 \%$ ). A gradual further weight loss of $15 \%$ occurs in the range $150-430{ }^{\circ} \mathrm{C}$, consistent with the evolution of DMF solvent molecules coordinated to the metal sites (3 DMF molecules corresponds to $16 \%$ ). Further heating prompts decomposition at $450{ }^{\circ} \mathrm{C}$. In the TG trace of 2 , a $30 \%$ weight loss occurs below $50{ }^{\circ} \mathrm{C}$, corresponding roughly to the evolution of 5 methanol and 10 water molecules $(29 \%)$. A gradual weight loss of $8 \%$ then follows up to $410{ }^{\circ} \mathrm{C}$, consistent with the loss of 3 metalcoordinated methanol molecules, and further heating induces decomposition.

The foregoing observations are consistent with thermodiffractometric analyses (see Fig. 6 and S9, ESI $\dagger$ ). These results confirm the high thermal stability of $\mathbf{1}$ and $\mathbf{2}$, while also showing 


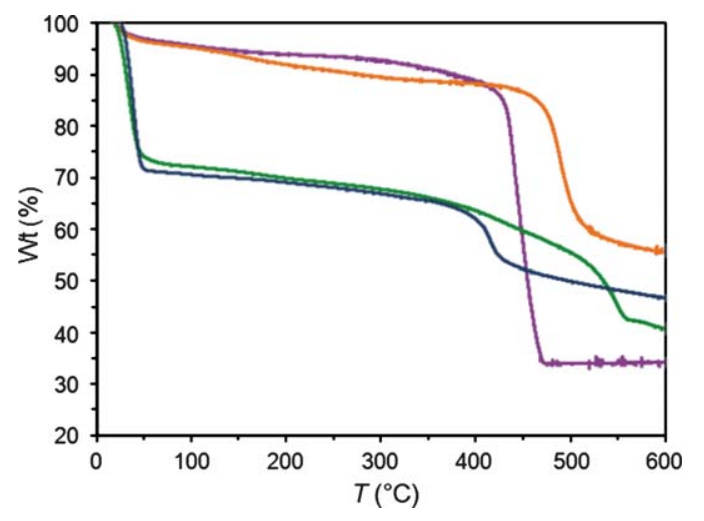

Fig. 5 Thermal gravimetric analysis of as-synthesized $\mathrm{Ni}_{3}(\mathrm{BTP})_{2} \cdot 3 \mathrm{DMF} \cdot 5 \mathrm{CH}_{3} \mathrm{OH} \cdot 17 \mathrm{H}_{2} \mathrm{O} \quad(\mathbf{1}, \quad$ green $), \quad \mathrm{Cu}_{3}(\mathrm{BTP})_{2} \cdot 8-$ $\mathrm{CH}_{3} \mathrm{OH} \cdot 10 \mathrm{H}_{2} \mathrm{O}$ (2, blue), $\mathrm{Zn}_{3}(\mathrm{BTP})_{2} \cdot 4 \mathrm{CH}_{3} \mathrm{OH} \cdot 2 \mathrm{H}_{2} \mathrm{O}$ (3, orange) and $\mathrm{Co}_{3}(\mathrm{BTP})_{2} \cdot 8 \mathrm{CH}_{3} \mathrm{OH} \cdot 10 \mathrm{H}_{2} \mathrm{O}(4$, purple).

that their crystallinity is retained to afford permanent porosity. Indeed, solvent loss does not significantly affect the crystal structures, with the powder diffraction patterns remaining largely unchanged up to $450^{\circ} \mathrm{C}$ for $\mathbf{1}$ and $390^{\circ} \mathrm{C}$ for $\mathbf{2}$. Notably, parametric Le Bail refinements against the data show that the two compounds respond to heat with a distinct framework
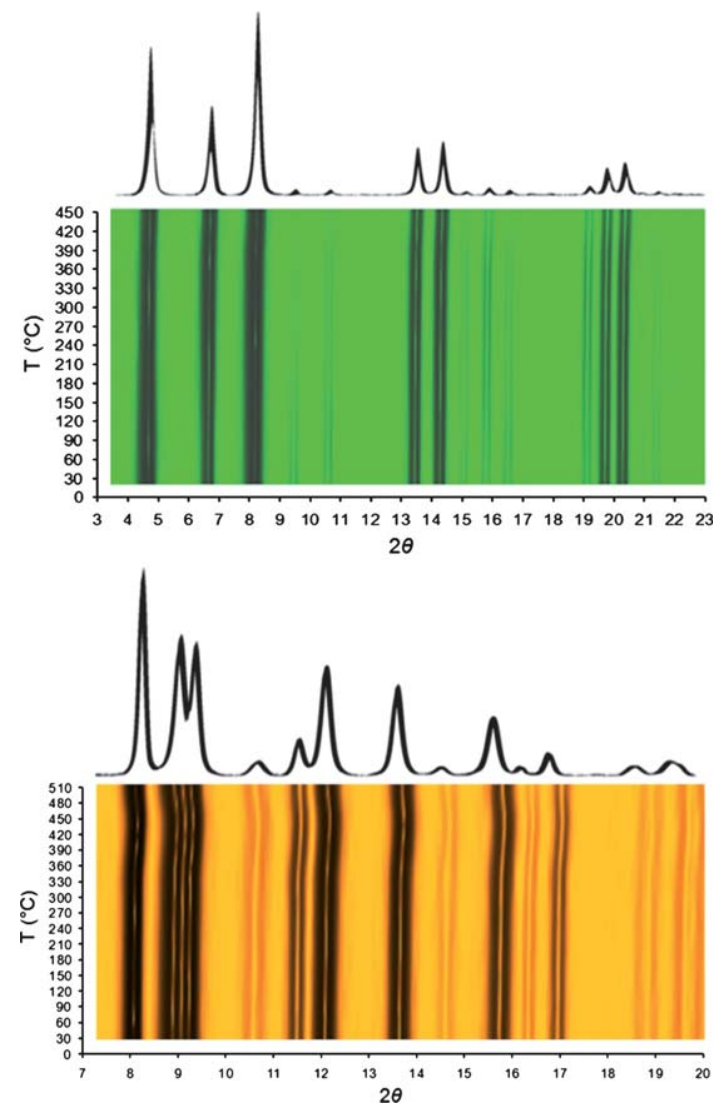

Fig. 6 Overlaid powder X-ray diffraction patterns measured at elevated temperatures in the range $30-450{ }^{\circ} \mathrm{C}$ for $\mathbf{1}$ (upper) and $30-510{ }^{\circ} \mathrm{C}$ for 3 (lower), and their two-dimensional contour plots as a function of $2 \theta$ and temperature, both displaying their thermal stability. Notably, the diffraction patterns remained unaltered during the measurements except for minor changes in peak intensity occurring at above $400{ }^{\circ} \mathrm{C}$. flexibility. In the case of $\mathbf{1}$, the unit cell volume remains almost constant up to $c a .200{ }^{\circ} \mathrm{C}$, while above this temperature, a modest contraction, reaching $0.5 \%$, is observed. In comparison, the unit cell volume of $\mathbf{2}$ experiences a modest, yet continuous, decrease in the temperature range $30-350{ }^{\circ} \mathrm{C}$, reaching $0.8 \%$ (see Fig, S10 and $\mathrm{S} 11, \mathrm{ESI} \dagger)$.

As evidenced by their thermal behavior, compounds 3 and 4 provide further examples of robust metal-organic frameworks. The thermogravimetric traces show less weight loss than expected on the basis of the pore solvent contents. For example, an $18 \%$ weight loss is expected for 3 , corresponding to 4 methanol and 2 water molecules, but only a $12 \%$ loss is observed for both 3 and 4 in the temperature range $30-500{ }^{\circ} \mathrm{C}$ (see Fig. 5). This discrepancy is reasonably due to solvent evolution during weighing and transferring the sample, particularly in view of the hydrophobic nature of the pore surfaces within these compounds. After solvent removal, decomposition begins at 510 and $450{ }^{\circ} \mathrm{C}$ for 3 and $\mathbf{4}$, respectively. The remarkably high thermal stability of $\mathbf{3}$ was confirmed by diffraction measurements, which also revealed retention of the structure upon heating in air (see Fig. 6). A parametric Le Bail refinement of the data revealed this compound to be an extremely rigid material, showing a very limited volume changes upon heating. At lower temperatures, this suggests that the partial, and very limited, desolvation overcomes thermal expansion effects (see Fig. S12, ESI $\dagger$ ). Notably, among all the members of the $\mathrm{M}_{3}(\mathrm{BTP})_{2}$ family, the tetragonal zinc(II) derivative shows the greatest thermal stability. Indeed, in this regard, zinc(II) compounds have proven superior to other metal(II) analogues for all of the pyrazolatebridged metal-organic frameworks reported so far. In the cases of $\mathrm{M}(2 \text {-pymo })_{2}$ and $\mathrm{M}(4 \text {-pymo })_{2}$ compounds, the highest tolerances to elevated temperatures have also been found for $\mathrm{M}=$ $\mathrm{Zn}^{24}$

\section{Chemical stability}

The chemical resistance of $\mathbf{1 - 3}$ was examined by suspending samples of the compounds in boiling water, boiling aqueous $\mathrm{HCl}$ or $\mathrm{HNO}_{3}$ solutions at $\mathrm{pH}$ 2, and a boiling aqueous $\mathrm{NaOH}$ solution at $\mathrm{pH} \mathrm{14}$, conditions that reflect extreme operational parameters in industry. Each sample ( $c a .100 \mathrm{mg}$ ) was soaked in the applicable test solution, which was subsequently heated at $100{ }^{\circ} \mathrm{C}$ for two weeks. During this period of time, a portion of each sample was periodically removed, filtered, dried at room temperature and checked by X-ray powder diffraction analysis. For compound 1, after each two-week treatment, the sample was desolvated by heating at $250{ }^{\circ} \mathrm{C}$ and $\mathrm{N}_{2}$ adsorption isotherms were collected at $77 \mathrm{~K}$ to test retention of surface area.

Remarkably, the $\mathrm{Ni}_{3}(\mathrm{BTP})_{2}$ framework of $\mathbf{1}$ is stable to all of the environments tested and maintains both its crystallinity and porous nature after 14 days of uninterrupted test reactions. Powder X-ray diffraction data collected before and after each test confirm its structural chemical integrity (see Fig. 7). No change in crystallinity was observed, but only in the intensities of the peaks, which is reasonably due to the difference in solvent contents. The accessibility of the pores within the retained structure was unequivocally demonstrated by measuring the surface areas of the solid after each chemical stability test (see Table 1). Significantly, 1 retains its surface area after two weeks 


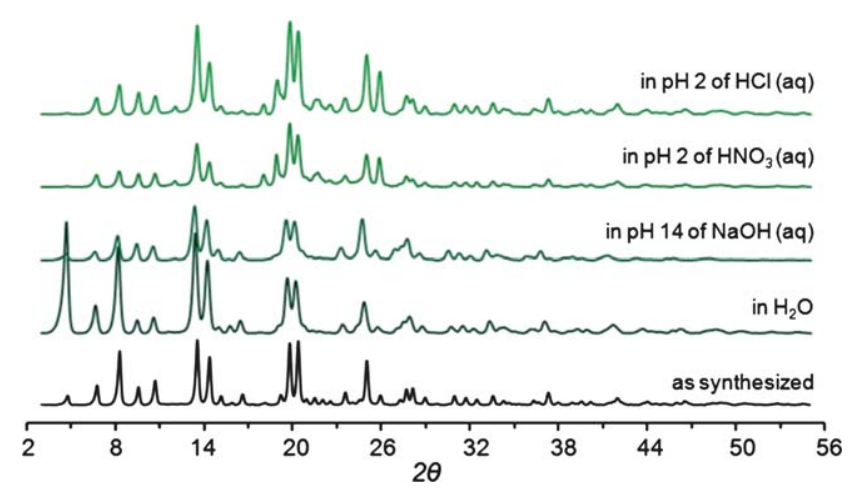

Fig. 7 X-Ray diffraction patterns for 1 after treatment in water, acids or base for two weeks at $100{ }^{\circ} \mathrm{C}$.

under all of the aforementioned extreme conditions. To our knowledge, this is the most extensive range of chemical stability yet demonstrated for a metal-organic framework. Although some frameworks are chemically resistant in a basic solution, none have been known to be stable in a $\mathrm{pH} 2$ acid solution at $100{ }^{\circ} \mathrm{C}$. Some imidazolate-based frameworks are known to be substantially retained in boiling solvents (water, methanol, benzene) for 7 days, yet only for $24 \mathrm{~h}$ in aqueous $\mathrm{NaOH}$ solution, with a poor stability in acidic solutions reported. The zirconiumbased framework UIO-66, ${ }^{7 b}$ has been shown to display thermal stability up to $540{ }^{\circ} \mathrm{C}$, but its chemical stability in water and common organic solvents was verified only for no longer than $24 \mathrm{~h}$ at room temperature. Other stability studies on tetrazolate- ${ }^{10 b}$ triazolate-, ${ }^{12}$ and pyrazolate-based ${ }^{7 e, 15}$ frameworks have been performed but, despite their sometimes good water tolerance, the chemical stability in acidic and basic media is either inferior to 1 or not reported. Combined with its exceptional stability, the presence of exposed metal cation sites in $\mathbf{1}$, typically the preferred binding sites for adsorbates (including nonpolar species like $\mathrm{H}_{2}$ ), should raise its potential for a variety of applications.

In contrast, the copper- and zinc-based frameworks of $\mathbf{2}$ and $\mathbf{3}$, undergo transformation to non-porous crystalline solids upon extreme chemical treatment, as rather commonly observed for metal-organic frameworks. As depicted in Fig. 8, compound 2 shows a progressive phase transition in boiling water, converting to $\mathbf{2}^{\prime}$. This transformation occurs upon refluxing $\mathbf{2}$ in aqueous $\mathrm{NaOH}(\mathrm{pH} 14)$ or $\mathrm{HCl}(\mathrm{pH} 3)$ solutions for one day. The longest resistance of $\mathbf{2}$ to $\mathrm{pH} 14$ solution at room temperature was found

Table 1 Langmuir surface areas for compound 1 as-synthesized and after treatment with boiling water, $\mathrm{HCl}_{(\mathrm{aq})}$ at $\mathrm{pH} 2, \mathrm{HNO}_{3(\mathrm{aq})}$ at $\mathrm{pH} 2$ and $\mathrm{NaOH}_{(\mathrm{aq})}$ at $\mathrm{pH} 14 .^{a}$

\begin{tabular}{ll}
\hline Conditions & $\mathrm{SA}_{\text {Langmuir }} / \mathrm{m}^{2} \mathrm{~g}^{-1}$ \\
\hline As-synthesized & $1900(13)$ \\
$\mathrm{H}_{2} \mathrm{O}$ & $1830(10)$ \\
$\mathrm{HCl}_{(\mathrm{aq})}$ & $1791(14)$ \\
$\mathrm{HNO}_{3(\text { aq) }}$ & $1774(11)$ \\
$\mathrm{NaOH}_{(\mathrm{aq})}$ & $1925(15)$
\end{tabular}

${ }^{a}$ Values were obtained from $\mathrm{N}_{2}$ adsorption measurements performed at $77 \mathrm{~K}$ on samples subjected to the conditions specified for two weeks and then desolvated by heating at $250{ }^{\circ} \mathrm{C}$ under dynamic vacuum.
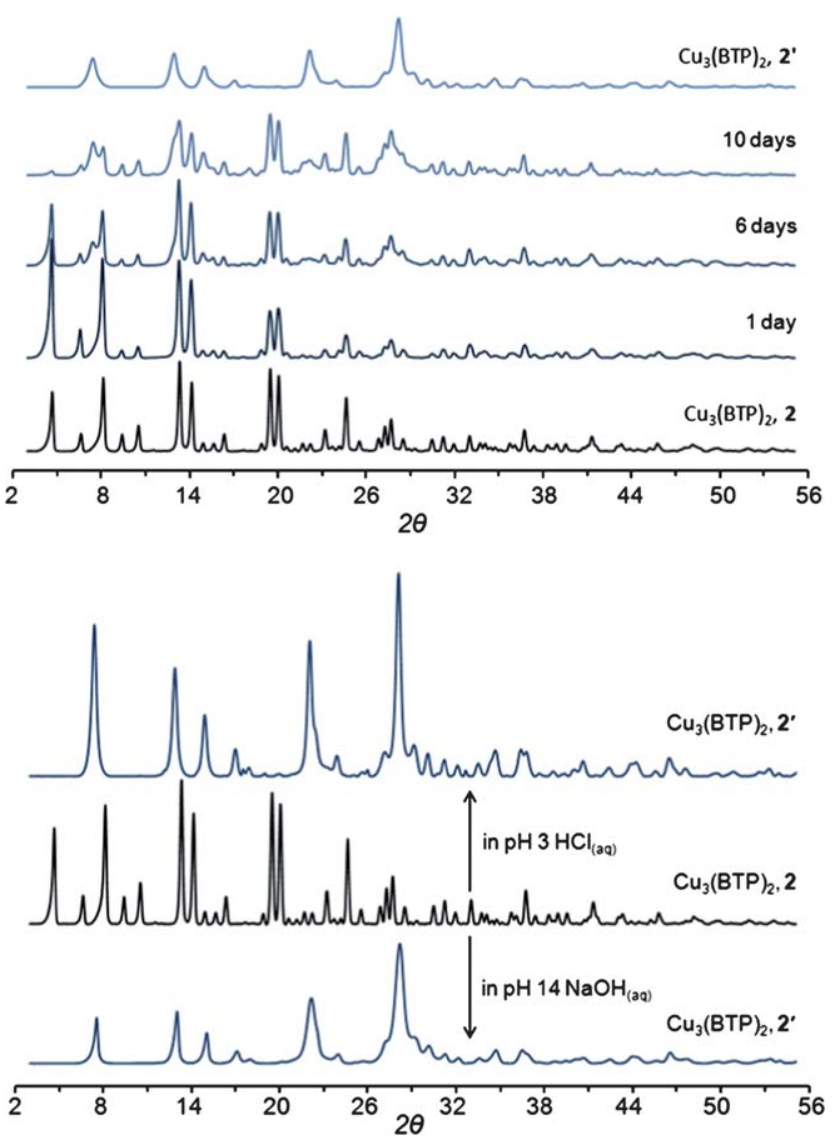

Fig. 8 Powder X-ray diffraction patterns of $\mathbf{2}$ during treatment in water for 14 days at $100^{\circ} \mathrm{C}$ (top) and transformation of $\mathbf{2}$ in $\mathbf{2}^{\prime}$ after treatment in an acidic or a basic solution (bottom).

to be one day, and it was further found to be stable for two weeks in benzene, DMF and methanol heated at reflux (see Fig. S15, ESI $\dagger$ ). Despite its extremely high thermal stability, compound 3 displays a resistance to hot acidic media that is somewhat inferior to that of $\mathbf{1}$. While its structure is maintained upon heating at $100{ }^{\circ} \mathrm{C}$ in $\mathrm{pH} 3$ aqueous $\mathrm{HCl}$ for 7 days, as shown in Fig. 9, it is not stable to a similar treatment at $\mathrm{pH} 2$. In addition, 3 reacts in

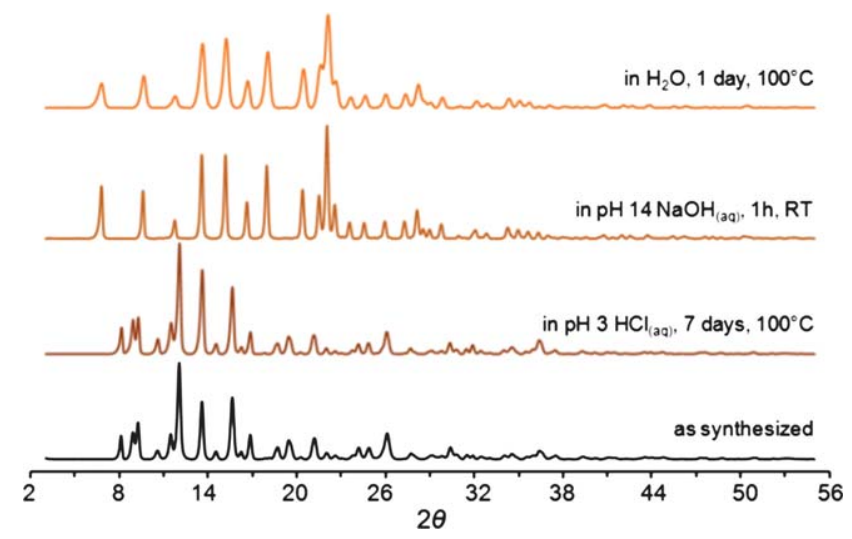

Fig. 9 Powder X-ray diffraction patterns of $\mathbf{3}$ after treatment in water, acid or base for various durations at various temperatures. 
water and especially in basic solutions, transforming into the cubic phase $\mathbf{3}^{\prime}$.

\section{Conclusions}

The foregoing results demonstrate the use of the new triangular trispyrazole molecule $\mathrm{H}_{3} \mathrm{BTP}$ in construction of microporous frameworks of the type $\mathrm{M}_{3}(\mathrm{BTP})_{2}(\mathrm{M}=\mathrm{Co}, \mathrm{Ni}, \mathrm{Cu}, \mathrm{Zn})$ exhibiting exceptional thermal and chemical stability. In particular, $\mathrm{Ni}_{3}(\mathrm{BTP})_{2}$ retains its integrity in the face of an unprecedented range of extreme conditions, including heating in air to $430{ }^{\circ} \mathrm{C}$ and treatment with boiling aqueous solutions of $\mathrm{pH} 2$ to 14 for two weeks. Thus, this stability parallels, or even surpasses that of zeolites, where the presence of selectively removable $\mathrm{Al}$ sites makes their frameworks unstable in highly acidic and basic conditions. ${ }^{25}$ Moreover, $\mathrm{Ni}_{3}(\mathrm{BTP})_{2}$ represents the first highstability metal-organic framework with accessible metal sites lining the pore surfaces. Such a remarkable combination of properties may open the way for testing metal-organic frameworks in a variety of applications that currently employ zeolites under extreme conditions. Indeed, future efforts will focus on exploring the performance of these new high-surface area materials in various high-temperature catalytic processes, as well as on the synthesis of other pyrazolate-based metal-organic frameworks featuring exposed metal sites.

\section{Acknowledgements}

This research was supported in the US by the Department of Energy under Contract No. DE-AC02-05CH11231 and in Italy by Fondazione Cariplo (Project 2007-5117). We thank Dr Leslie J. Murray, and Mr. Eric D. Bloch for helpful discussions.

\section{Notes and references}

1 (a) A. Corma, Chem. Rev., 1997, 97, 2373; (b) T. Maesen and B. Marcus, Introduction to Zeolite Science and Practice, 2001, eds. H. Van Bekkum, E. M. Flanigen, P. A. Jacobs and J. C. Jansen, Elsevier, Amsterdam, ch. 1-9; (c) D. H. Lauriente and Y. Inoguchi, The Chemical Economics Handbook, SRI Consulting, 2005, 599 1000 F, 14, 6; (d) B. Yilmaz and U. Muller, Top. Catal., 2009, 52, 888. 2 (a) M. Eddaoudi, J. Kim, N. Rosi, D. Vodak, J. Wachter, M. O'Keeffe and O. M. Yaghi, Science, 2002, 295, 469; (b) S. Kitagawa, R. Kitaura and S. I. Noro, Angew. Chem., Int. Ed., 2004, 43, 2334; (c) G. Férey, Chem. Soc. Rev., 2008, 37, 191; (d) J. R. Long and O. M. Yaghi, Chem. Soc. Rev., 2009, 38, 1213.

3 (a) K. K. Tanabe and S. M. Cohen, Chem. Soc. Rev., 2011, 40, 498; (b) S. M. Cohen, Chem. Sci., 2010, 1, 32; (c) Z. Wang and S. M. Cohen, Chem. Soc. Rev., 2009, 38, 1315; (d) T. Ahnfeldt, D. Gunzelmann, T. Loiseau, D. Hirsemann, J. Senker, G. Férey and N. Stock, Inorg. Chem., 2009, 48, 3057; (e) Y. K. Hwang, D.-Y. Hong, J.-S. Chang, S. H. Jhung, Y.-K. Seo, J. Kim, A. Vimont, M. Daturi, C. Serre and G. Férey, Angew. Chem., Int. Ed., 2008, 47, 4144; $(f)$ O. K. Farha, K. L. Mulfort and J. T. Hupp, Inorg. Chem., 2008, 47, 10223; $(g)$ K. L. Mulfort, O. K. Farha, C. L. Stern, A. A. Sarjeant and J. T. Hupp, J. Am. Chem. Soc., 2009, 131, 3866; (h) Y.-S. Bae, O. K. Farha, J. T. Hupp and R. Q. Snurr, J. Mater. Chem., 2009, 19, 2131; (i) M. J. Ingleson, J. P. Barrio, J.B. Guilbaud, Y. Z. Khimyak and M. J. Rosseinsky, Chem. Commun., 2008, 2680; (j) M. J. Ingleson, R. Heck, J. A. Gould and M. J. Rosseinsky, Inorg. Chem., 2009, 48, 9986; (k) D. Britt, C. Lee, F. J. Uribe-Romo, H. Furukawa and O. M. Yaghi, Inorg. Chem., 2010, 49, 6387; (l) K. Oisaki, Q. Li, H. Furukawa, A. C. Czaja and O. M. Yaghi, J. Am. Chem. Soc., 2010, 132, 9262; (m) M. Meilikow, K. Yusenko and R. A. Fischer, J. Am. Chem. Soc., 2009, 131, 9644.
4 (a) R. Matsuda, R. Kitaura, S. Kitagawa, Y. Kubota, R. V. Belosludov, T. C. Kobayashi, H. Sakamoto, T. Chiba, M. Takata, Y. Kavazoe and Y. Mita, Nature, 2005, 436, 238; (b) A. R. Millward and O. M. Yaghi, J. Am. Chem. Soc., 2005, 127, 17998; (c) H. Furukawa, M. A. Miller and O. M. Yaghi, J. Mater. Chem., 2007, 17, 3197; (d) S. Ma, D. Sun, J. M. Simmons, C. D. Collier, D. Yuan and H.-C. Zhou, J. Am. Chem. Soc., 2008, 130, 1012; (e) R. E. Morris and P. S. Wheatley, Angew. Chem., Int. Ed., 2008, 47, 4966; (f) P. L. Llewellyn, S. Bourrelly, C. Serre, A. Vimont, M. Daturi, L. Hamon, G. De Weireld, J.-S. Chang, D.Y. Hong, Y. K. Hwang, S. H. Jhung and G. Férey, Langmuir, 2008, 24, 7245; $(g)$ L. J. Murray, M. Dincă and J. R. Long, Chem. Soc. Rev., 2009, 38, 1294, and references therein.

5 (a) L. Pan, D. H. Olson, L. R. Ciemnolonski, R. Heddy and J. Li, Angew. Chem., Int. Ed., 2006, 45, 616; (b) H. Hayashi, A. P. Côté, H. Furukawa, M. O'Keeffe and O. M. Yaghi, Nat. Mater., 2007, 6, 501; (c) K. A. Cychosz, A. G. Wong-Foy and A. J. Matzger, J. Am. Chem. Soc., 2008, 130, 6938; (d) D. Britt, D. J. Tranchemontagne and O. M. Yaghi, Proc. Natl. Acad. Sci. U. S. A., 2008, 105, 11623; (e) D. Britt, H. Furukawa, B. Wang, T. G. Glover and O. M. Yaghi, Proc. Natl. Acad. Sci. U. S. A., 2009, 106, 20637; (f) J.-R. Li, R. J. Kuppler and H.-C. Zhou, Chem. Soc. Rev., 2009, 38, 1477; (g) L. J. Murray, M. Dinca, J. Yano, S. Chavan, S. Bordiga, C. M. Brown and J. R. Long, J. Am. Chem. Soc., 2010, 132, 7856.

6 (a) J. S. Seo, D. Whang, H. Lee, S. I. Jun, J. Oh, Y. J. Jeon and K. Kim, Nature, 2000, 404, 982; (b) C.-D. Wu, A. Hu, L. Zhang and W. Lin, J. Am. Chem. Soc., 2005, 127, 8940; (c) S. Horike, M. Dincă, K. Tamaki and J. R. Long, J. Am. Chem. Soc., 2008, 130, 5854; (d) L. Ma, C. Abney and W. Lin, Chem. Soc. Rev., 2009, 38, 1248; (e) J. Lee, O. K. Farha, J. Roberts, K. A. Scheidt, S. T. Nguyen and J. T. Hupp, Chem. Soc. Rev., 2009, 38, 1450.

7 (a) K. S. Park, Z. Ni, A. P. Côté, J. Y. Choi, R. Huang, F. J. UribeRomo, H. K. Chae, M. O'Keeffe and O. M. Yaghi, Proc. Natl. Acad. Sci. U. S. A., 2006, 103, 10186; (b) J. Hafizovic Cavka, S. Jacobsen, U. Olsbye, N. Guillou, C. Lamberti, S. Bordiga and K. P. Lillerud, J. Am. Chem. Soc., 2008, 130, 13850; (c) T. Loiseau, C. Huguenard, G. Fink, F. Taulelle, M. Henry, T. Bataille and G. Férey, Chem.Eur. J., 2004, 10, 1373; (d) S. Galli, N. Masciocchi, V. Colombo, A. Maspero, G. Palmisano, F. J. Lopez-Garzon, M. DomingoGarcía, I. Fernandez-Morales, E. Barea and J. A. R. Navarro, Chem. Mater., 2010, 22, 1664; (e) H. J. Choi, M. Dincă, A. Dailly and J. R. Long, Energy Environ. Sci., 2010, 3, 117; $(f)$ N. Masciocchi, S. Galli, V. Colombo, A. Maspero, G. Palmisano, B. Seyyedi, C. Lamberti and S. Bordiga, J. Am. Chem. Soc., 2010, 132, 7902; $(g)$ O. K. Farha, A. M. Spokoyny, K. L. Mulfort, M. F. Hawthorne, C. A. Mirkin and J. T. Hupp, J. Am. Chem. Soc., 2007, 129, 12680; (h) J.-P. Zhang and S. Kitagawa, J. Am. Chem. Soc., 2008, 130, 907.

8 (a) S. S. Kaye, A. Dailly, O. M. Yaghi and J. R. Long, J. Am. Chem. Soc., 2007, 129, 14176; (b) M. Eddaudi, D. B. Moler, H. Li, B. Chen, T. M. Reineke, M. O'Keeffe and O. M. Yaghi, Acc. Chem. Res., 2001, 34, 319.

9 (a) J. A. Greathouse and M. D. Allendorf, J. Am. Chem. Soc., 2006, 128, 10678; (b) J. J. Low, A. I. Benin, P. Jakubczak, J. F. Abrahamian, S. A. Faheem and R. R. Willis, J. Am. Chem. Soc., 2009, 131, 15834.

10 (a) A. Cingolani, S. Galli, N. Masciocchi, L. Pandolfo, C. Pettinari and A. Sironi, J. Am. Chem. Soc., 2005, 127, 6144; (b) M. Dincă, A. F. Yu and J. R. Long, J. Am. Chem. Soc., 2006, 128, 8904; (c) A. Maspero, S. Galli, V. Colombo, G. Peli, N. Masciocchi, S. Stagni, E. Barea and J. A. R. Navarro, Inorg. Chim. Acta, 2009, 362, 4340; (d) A. Demessence and J. R. Long, Chem.-Eur. J., 2010, 16, 5902 .

11 F. G. Bordwell, Acc. Chem. Res., 1988, 21, 456. Note that the values given are for the non-substituted azoles, and are referenced to DMSO.

12 A. Demessence, D. M. D'Alessandro, M. L. Foo and J. R. Long, J. Am. Chem. Soc., 2009, 131, 8784.

13 H. J. Choi, M. Dincă and J. R. Long, J. Am. Chem. Soc., 2008, 130, 7848 .

14 (a) M. Dincă, A. Dailly, Y. Liu, C. M. Brown, D. A. Neumann and J. R. Long, J. Am. Chem. Soc., 2006, 128, 16876; (b) M. Dincă, W. S. Han, Y. Liu, A. Dailly, C. M. Brown and J. R. Long, Angew. Chem., Int. Ed., 2007, 46, 1419; (c) M. Dinca and J. R. Long, Angew. Chem., Int. Ed., 2008, 47, 6766. 
15 E. Quartapelle-Procopio, F. Liñares, C. Montoro, V. Colombo, A. Maspero, E. Barea and J. A. R. Navarro, Angew. Chem., Int. Ed., 2010, 49, 7308 .

16 PLATON: A. L. Spek, Acta Crystallogr., Sect. A, 1990, 46, C34.

17 Due to the extreme rigidity of the frameworks, the values quoted are representative of the void volume of the outgassed counterparts.

18 Due to the heavy disorder affecting the solvent molecules in the structure, both clathrated and coordinated, their electron density has been described by a very simplified model. For further details the reader is addressed to the ESI $\dagger$.

19 To build the rigid model describing the ligand, the following bond distances and angles have been adopted (a) for the benzene ring: $\mathrm{C}-$ $\mathrm{C}=1.39 \AA$; $\mathrm{C}-\mathrm{H}=0.95 \AA$; $\mathrm{C}-\mathrm{C}-\mathrm{C}, \mathrm{C}-\mathrm{C}-\mathrm{H}=120^{\circ}$; (b) for the pyrazole ring: $\mathrm{C}-\mathrm{C}, \mathrm{C}-\mathrm{N}, \mathrm{N}-\mathrm{N}=1.36 \AA$; $\mathrm{C}-\mathrm{H}=0.95 \AA$; internal ring angles $=108^{\circ} ; \mathrm{C}-\mathrm{C}-\mathrm{H}=126^{\circ} . \mathrm{C}_{\text {benzene }}-\mathrm{C}_{\text {pyrazole }}=1.45 \AA$.

20 (a) K. Sumida, S. Horike, S. S. Kaye, Z. R. Herm, W. L. Queen, C. M. Brown, F. Grandjean, G. J. Long, A. Dailly and J. R. Long, Chem. Sci., 2010, 1, 184; (b) K. Sumida, S. Horike, E. D. Bloch, M. L. Foo, L. J. Murray and J. R. Long, unpublished results.
21 (a) N. Masciocchi, G. A. Ardizzoia, A. Maspero, G. LaMonica and A. Sironi, Inorg. Chem., 1999, 38, 3657; (b) A. P. Sadimenko and S. S. Basson, Coord. Chem. Rev., 1996, 147, 247.

22 (a) W. Evans, J. Chem. Educ., 2004, 81, 1191; (b) J. G. Vos and W. L. Groeneveld, Transition Met. Chem., 1979, 4, 137.

23 J. A. R. Navarro, E. Barea, J. M. Salas, N. Masciocchi, S. Galli, A. Sironi, C. O. Ania and J. B. Parra, Inorg. Chem., 2006, 45, 2397.

24 (a) N. Masciocchi, G. A. Ardizzoia, G. LaMonica, A. Maspero and A. Sironi, Eur. J. Inorg. Chem., 2000, 2507; (b) E. Barea, J. A. R. Navarro, J. M. Salas, N. Masciocchi, S. Galli and A. Sironi, Inorg. Chem., 2004, 43, 473.

25 (a) A. Cizmek, L. Komunjer, B. Subotic, M. Siroki and S. Roncevic, Zeolites, 1991, 11, 258; (b) A. Cizmek, L. Komunjer, B. Subotic, M. Siroki and S. Roncevic, Zeolites, 1991, 11, 810; (c) A. Cizmek, L. Komunjer, B. Subotic, M. Siroki and S. Roncevic, Zeolites, 1992, 12, 190; (d) A. Petushkov, J. Freeman and S. C. Larsen, Langmuir, 2010, 26, 6695; (e) R. L. Hartman and H. S. Fogler, Langmuir, 2007, 23, 5477; ( $f$ ) K. J. Murata, J. Am. Mineral., 1943, 28, 545 . 